\title{
Communication between pre-hospital and intra-hospital emergency medical services: literature review
}

\author{
A comunicação entre os serviços médicos de emergência pré-hospitalar e intra-hospitalar: revisão de literatura
}

La comunicación entre los servicios médicos de emergencia pre-hospitalaria e intra-hospitalaria revisión de literatura

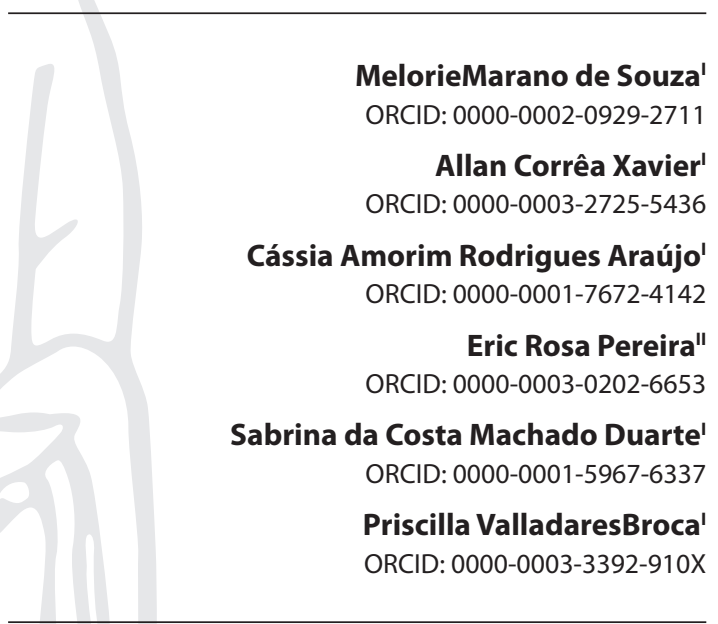

'Universidade Federal do Rio de Janeiro. Rio de Janeiro, Rio de Janeiro, Brazil.

"Fundação Técnico-Educacional Souza Marques. Rio de Janeiro, Rio de Janeiro, Brazil.

How to cite this article: Souza MM, Xavier AC, Araújo CAR, Pereira ER, Duarte SCM Broca PV. Communication between pre-hospital and intrahospital emergency medical services: literature review. RevBrasEnferm. 2020;73(Suppl 6):e20190817. doi: http://dx.doi.org/10.1590/0034-7167-2019-0817

Corresponding author:

Priscilla Valladares Broca E-mail: priscillabroca@gmail.com

EDITOR IN CHIEF: Dulce Barbosa ASSOCIATE EDITOR: Alexandre Balsanelli

\section{ABSTRACT}

Objectives:to analyze, according to the scientific literature, communication strategies in the transfer of cases between pre-hospital and in-hospital services and their contributions to patient safety. Methods: this is a literature review study, that is, one that aims to gather and synthesize research results on the subject in a systematic and orderly manner.Results: ten articles were published, published between 2010 and 2018, and two points of discussion emerged: use of mnemonics; and barriers to transferring a case. Conclusions: studies point to the need to standardize the case transfer process, as well as integrative training of professionals, regular assessment of the teams involved in emergency medical services and the need for research on the subject.

Descriptors: Communication; Emergency Medical Services; Ambulance; Transfer of Responsibility by the Patient; Review.

\section{RESUMO}

Objetivos:analisar, de acordo com a literatura científica, estratégias de comunicação na transferência de caso entre os serviços pré-hospitalar e intra-hospitalar e suas contribuições para a segurança do paciente. Métodos: trata-se de um estudo de revisão de literatura, isto é, aqueleque tem como finalidade reunir e sintetizar resultados de pesquisas sobre a temática de maneira sistemática e ordenada.Resultados: foram selecionados dez artigos, publicados entre 2010 e 2018, emergindo dois pontos de discussão: uso de mnemônicos; e barreiras para a transferência de caso. Conclusões: os estudos apontam para a necessidade de padronização do processo de transferência de caso, bem como treinamento integrativo dos profissionais, avaliação regular das equipes envolvidas nos serviços médicos de emergência e necessidade de pesquisa acerca da temática.

Descritores: Comunicação; Serviços Médicos de Emergência; Ambulância; Transferência da Responsabilidade pelo Paciente; Revisão.

\section{RESUMEN}

Objetivos:analizar, de acuerdo con la literatura científica, estrategias de comunicación en la transferencia de caso entre los servicios pre-hospitalaria e intra-hospitalariae sus contribuciones para la seguridad del paciente. Métodos: se trata de un estudio de revisión de literatura, es decir, aquel que tiene como finalidad reunir y sintetizar resultados de investigaciones sobre la temática de manera sistemática y ordenada.Resultados: han sido recogidos diez artículos, publicados entre 2010 y 2018, emergiendo dos puntos de discusión: uso de nemotécnicos; y barreras para la transferencia de caso. Conclusiones: los estudios apuntan para la necesidad de estandarización del proceso de transferencia de caso, así como entrenamiento integrador de los profesionales, evaluación regular de los equipos envueltos en los servicios médicos de emergencia y necesidad de investigación acerca de la temática.

Descriptores: Comunicación; Servicios Médicos de Emergencia; Ambulancia;Transferencia de la Responsabilidad por el Paciente; Revisión. 


\section{INTRODUCTION}

Communication is a dynamic process and inherent to the nature of care. In health, it involves direct communication with the patient and also between professionals ${ }^{(1)}$, the latter being of great concern to bodies such as the World Health Organization (WHO) and the Joint Commission International ( $\mathrm{JCl}$ ), given that it is still a major source of errors, which can lead to adverse events compromising patient safety ${ }^{(2-3)}$.

Both institutions joined forces to set goals that could reduce the negative impact of health actions on patients: the second goal is specifically about improving communication between health professionals ${ }^{(4)}$, because this is the most common cause of errors, generating deaths, high cost in hospital expenses, in addition to other factors, such as pain and sequelae to the patient ${ }^{(2)}$.

This scenario becomes even more serious when it comes to transferring the patient's case between the pre-hospital and inhospital stages of the emergency services. Due to the dynamic nature as well as the speed with which interventions must be carried out, communication can end up being impaired, directly causing delays and errors in diagnoses, treatment and in choosing the best conduct for the patient ${ }^{(5)}$.

When the communication process does not proceed properly, it fails in two distinct but predictable ways: silence and violence ${ }^{(3,6)}$. In the silence, important information and concerns are not passed on, or are passed on to the wrong people; and in violence, verbal attacks, sarcasm and other ways of labeling or disqualifying another professional can arise. These situations can be observed in different health professions and cause low commitment from professionals, weaken institutions and generate burdens.

Account must also be taken of the burden on emergency services, considering the pre-hospital and intra-hospital aspects, as well as structural problems and the weakness of the reference system, the latter, further hampered by the capacity of the doors of hospitals offering urgent and emergency services, with demands that could be met in Primary Health Care.

In addition, there is a difficulty in the training of health professionals and the lack of resources. These facts have a direct impact on the quality of care, as they add to the teams a greater workload and stress, considering also a chronic under-dimensioning of professionals from the most diverse areas ${ }^{(7)}$.

In Brazil, the mobile pre-hospital care system began to be structured based on Ordinance No. 2048, of November 25, 2002, which provided a solid basis for the organization of these services $^{(8)}$. In 2003, the National Emergency Care Policy was created, culminating in the establishment of the Mobile Emergency Care Service (SAMU) $)^{(9)}$, where basic life support units are composed of at least one driver and a nursing technician; and advanced life support units are minimally composed of a doctor and a nurse, in addition to the driver ${ }^{(10)}$.

Calls from the population to 192 are forwarded to a central office, where a technician receives the first information and passes it on to a regulatory doctor, which, according to the collected history, will decide what type of ambulance to send to the place and its final destination, always looking for a referral hospital for the situation found ${ }^{(11)}$.
Considering all the impact of communication from prehospital services to intra-hospital services, as well as the scarcity of the theme in the scientific literature, the relevance of this study stands out. In this sense, there is a lack of protocols that guide the transfer of the patient's case between the segments of care, lack of training of professionals involved in this context, as well as the still recent action of trying to organize urgent and emergency services.

The following research question was then established: What are the main evidences about the communication between health professionals during the transfer of the case between the pre-hospital and in-hospital emergency services?

\section{OBJECTIVES}

To analyze, according to the scientific literature, communication strategies in the transfer of cases between pre-hospital and in-hospital services and their contributions to patient safety.

\section{METHODS}

\section{Study type}

This is a literature review study, that is, one whose purpose is to gather and synthesize research results on a certain topic or issue, in a systematic and orderly manner, contributing to the deepening of the investigated subject ${ }^{(12)}$. The review process followed the step by step of the research protocol "Main Items for Reporting Systematic Reviews and Meta-analyzes" (PRISMA) ${ }^{(13)}$, which is registered in the International Database of Systematic Review Protocols.

\section{Methodological procedures}

For the elaboration of this study, the following steps were delimited: identification of the theme and its delimitation (development of the research question, definition of the descriptors, inclusion and exclusion criteria of studies for the review); sampling; classification of studies; definition of the information to be extracted from the reviewed papers; analysis of the theme found in the literature; synthesis of the knowledge evidenced in the analyzed studies; and presentation of the integrative review $^{(12)}$.

\section{Data collection and organization}

Data collection took place in January 2018, in the Web of Science, LILACS, Scopus, CINAHL and MEDLINE databases, using the Health Sciences Descriptors (DeCS) "Health Communication", "Emergency Medical Services" and "Ambulance", as well as the corresponding descriptors in English "Health Communication", "Emergency Medical Services" and "Ambulance".

The descriptors used were chosen because they were able to portray in a coherent and objective way what was identified in the searches. The descriptor "Communication in Health" corresponds to studies and communication strategies to inform decisions that promote health; o "Emergency Medical Services" 
is related to services that provide emergency care, such as prehospital care, SAMU, emergency centers, emergency rooms, among others; and "Ambulance" refers to vehicles equipped to transport patients. Thus, the articles that worked with the communication of the case transfer between the pre-hospital and in-hospital services were captured.

To elaborate the combinations between the descriptors, the Boolean operator "and" was used between them, according to the following search strategies: Health Communication "and" Ambulance "and" Emergency Medical Services; Health Communication "and" Ambulance; Health Communication "and" Emergency Medical Services; Ambulance "and" Emergency Medical Services; Health Communication "and" Ambulance "and" Emergency Medical Services; Health Communication "and" Ambulance; Health Communication "and" Emergency Medical Services; Ambulance "and" Emergency Medical Services; Health Communication "and" Ambulance "and" Emergency Medical Services; Health Communication "and" Ambulance; Health Communication "and" Emergency Medical Services; Ambulance "and" Emergency Medical Services; Health Communication "and" Ambulance "and" Emergency Medical Services; Health Communication "and" Ambulance; Health Communication "and" Emergency Medical Services; Ambulance"and" Emergency Medical Services; and Ambulance "and" Emergency Medical Services.

\section{Data analysis}

From the findings in the databases, 14,545 articles were found, which were evaluated by applying the inclusion and exclusion criteria previously defined in the research protocol. The inclusion criteria adopted were: be an original article and complete review; free access; have a maximum of ten years of publication; be written in Portuguese, English and Spanish; and having as a central theme the communication process in the transfer of cases between professionals in the mobile emergency medical service and the in-hospital.

Reflective studies, research protocols, editorials, letters to editors, duplicate studies were excluded, as well as those that addressed pre-hospital activity in relation to decision-making algorithms, ambulance redirection, assessment of communication systems and air rescue.

Thereafter, the 28 articles were read in full to identify those who answered the research question satisfactorily and / or had relevance to the study objectives. After this analysis, a sample of ten articles was obtained, including: eight (80\%) from Web of Science and two (20\%) from Scopus. The flowchart detailing the research steps is shown below, in Figure 1.

The data of the articles were organized in an Excel table, in order to facilitate visualization for the analysis and interpretation of qualitative findings. This table contains a summary of the following information: title of the study, journal and year of publication, country of development of the study, study design, interventions and main outcomes. Based on the main interventions and outcomes, a qualitative analysis of this data was carried out, which supported the construction of the results and the discussion of this article.

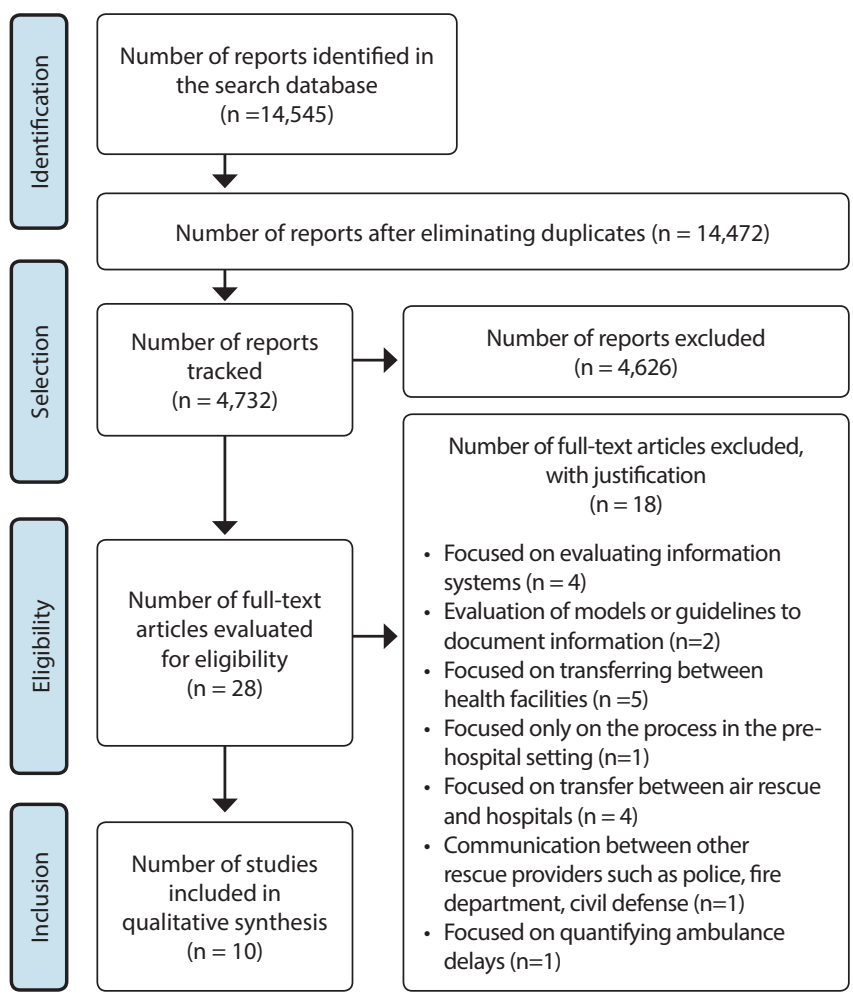

Figure 1 - Flowchart of data collection and analysis, according to the PRISMA model ${ }^{(13)}$

\section{RESULTS}

The ten selected articles were published in English, being found in seven different magazines, with emphasis on the Scandinavian Journal OfTrauma, Resuscitation and Emergency Medicine, with three $(30 \%)$ of the publications. As for the year, articles were published between 2010 and 2018, with emphasis on the years 2015, 2017 and 2018, each with two publications, representing, together, $60 \%$ of the selected articles.

Regarding the place of origin of the studies, there is a predominance of the European continent, accounting for eight articles, corresponding to $80 \%$ of publications, with the Netherlands responsible for three of these, representing 30\%. As for the publication area, multiprofessional publications predominated, accounting for $50 \%$ of publications, followed by medical publications, which represent $40 \%$ of publications.

Regarding the type of study, those of a qualitative nature prevailed, totaling nine (90.0\%) publications, and there was an article of a quantitative nature, corresponding to $10 \%$. Regarding the level of evidence of the articles, it was established based on the type of methodological approach adopted ${ }^{(14)}$ : nine articles have evidence 4, representing 90\%; and an article with level of evidence 2 , representing $10 \%$.

To facilitate the visualization of the results, Chart 2 presents the profile of the selected studies. Next, the two categories shown from the results of the selected studies are presented: use of mnemonic in the patient's case transfer process; and barriers to transferring a case. 
Chart 1 - Profile of the studies selected by the research

\begin{tabular}{|c|c|c|c|c|c|}
\hline Article title & $\begin{array}{c}\text { Year } \\
\text { Country }\end{array}$ & $\begin{array}{l}\text { Outline/ number of } \\
\text { participants }\end{array}$ & Recommendations & Conclusion & $\begin{array}{l}\text { Level of } \\
\text { evidence }\end{array}$ \\
\hline $\begin{array}{l}\text { The satisfaction } \\
\text { regarding handovers } \\
\text { between ambulance } \\
\text { and emergency } \\
\text { department nurses: an } \\
\text { observational study } \\
\text { Handover of Patients } \\
\text { From Prehospital } \\
\text { Emergency Services to } \\
\text { Emergency } \\
\text { Departments }^{(15)}\end{array}$ & $\begin{array}{c}2018 \\
\text { Netherlands }\end{array}$ & $\begin{array}{l}\text { Quantitative } \\
\text { prospective } \\
\text { observational study }\end{array}$ & $\begin{array}{l}\text { Further research to target the quality } \\
\text { of transfers can focus on the use of a } \\
\text { standardized protocol. }\end{array}$ & $\begin{array}{l}\text { The satisfaction of ambulance nurses } \\
\text { is mainly affected by the waiting } \\
\text { time and the presence of a doctor, } \\
\text { while the satisfaction of nurses } \\
\text { in the Emergency Department is } \\
\text { mainly affected by the use of delivery } \\
\text { instruments. }\end{array}$ & 2 \\
\hline $\begin{array}{l}\text { Handover of Patients } \\
\text { From Prehospital } \\
\text { Emergency Services } \\
\text { to Emergency } \\
\text { Departments: a } \\
\text { qualitative analysis } \\
\text { based on experiences }_{\text {of nurses }^{(16)}}\end{array}$ & $\begin{array}{l}2018 \\
\text { Spain }\end{array}$ & $\begin{array}{l}\text { Qualitative } \\
\text { descriptive / } 12 \\
\text { nurses }\end{array}$ & $\begin{array}{l}\text { To perform proper patient transfer, } \\
\text { the professional must identify himself } \\
\text { to the patient's receiving nurse and } \\
\text { pass on patient information in the } \\
\text { following order: patient identification, } \\
\text { reason for referral, past medical history } \\
\text { and baseline, if they know each other, } \\
\text { procedures performed before arrival } \\
\text { and patient response to treatment. } \\
\text { The emergency nurse must confirm } \\
\text { the correct receipt of all information, } \\
\text { repeating it or asking questions and } \\
\text { asking for clarification as needed. Verbal } \\
\text { communication should always be } \\
\text { copied with written material provided } \\
\text { by the nurse in the pre-hospital } \\
\text { emergency medical service. }\end{array}$ & $\begin{array}{l}\text { The essential information to be } \\
\text { included in patient transfers is: the } \\
\text { reason for referral; previous history, } \\
\text { including any information relevant } \\
\text { to the case; allergies to medications } \\
\text { and procedures performed with } \\
\text { an emphasis on medication } \\
\text { administration; and response to } \\
\text { treatment. }\end{array}$ & 4 \\
\hline $\begin{array}{l}\text { Perspectives of Patient } \\
\text { Handover among } \\
\text { Paramedics and } \\
\text { Emergency } \\
\text { Department } \\
\text { Members; a } \\
\text { Qualitative Study }{ }^{(17)}\end{array}$ & $\begin{array}{l}2017 \\
\text { Iran }\end{array}$ & $\begin{array}{l}\text { Descriptive } \\
\text { exploratory / } 25 \\
\text { professionals from } \\
\text { pre-hospital and in- } \\
\text { hospital emergency } \\
\text { services, including } \\
\text { paramedics and } \\
\text { nurses }\end{array}$ & $\begin{array}{l}\text { Patient transfer is a skill that requires } \\
\text { education and practice; therefore, in } \\
\text { this sense, in-service education is a } \\
\text { priority. }\end{array}$ & $\begin{array}{l}\text { Designing an appropriate } \\
\text { environment, recruiting appropriate } \\
\text { labor, providing adequate equipment } \\
\text { and clarifying expectations are some } \\
\text { strategies to improve patient delivery } \\
\text { between pre-hospital and in-hospital } \\
\text { services. }\end{array}$ & 4 \\
\hline $\begin{array}{l}\text { A review of enhanced } \\
\text { paramedic roles } \\
\text { during and after } \\
\text { hospital handover } \\
\text { of stroke, myocardial } \\
\text { infarction and trauma } \\
\text { patients }^{(18)}\end{array}$ & $\begin{array}{l}2017 \\
\text { United } \\
\text { Kingdom }\end{array}$ & $\begin{array}{l}\text { Systematic review / } \\
\text { no article responded } \\
\text { to the objective. } 36 \\
\text { studies in the full text } \\
\text { phase were selected } \\
\text { for narrative review. }\end{array}$ & $\begin{array}{l}\text { Due to the nature of the studies } \\
\text { identified, no strong recommendations } \\
\text { can be made about changing the } \\
\text { transfer or post admission functions of } \\
\text { ambulance paramedics to the hospital } \\
\text { for patients with critical time conditions. }\end{array}$ & $\begin{array}{l}\text { A "new wave" of paramedical research } \\
\text { is needed to inform the design of } \\
\text { transfer and feedback processes } \\
\text { with cost effective and health } \\
\text { impact resulting from improved } \\
\text { communication and interprofessional } \\
\text { sharing of clinical skills. }\end{array}$ & 4 \\
\hline $\begin{array}{l}\text { A national research } \\
\text { agenda for pre- } \\
\text { hospital emergency } \\
\text { medical services in the } \\
\text { Netherlands: a Delphi- } \\
\text { study }{ }^{(19)}\end{array}$ & $\begin{array}{l}2016 \\
\text { Netherlands }\end{array}$ & $\begin{array}{l}\text { Survey/ } 62 \text { specialists } \\
\text { in the field of pre- } \\
\text { hospital emergency } \\
\text { services }\end{array}$ & $\begin{array}{l}\text { Qualitative data collection is } \\
\text { recommended for researchers when } \\
\text { they want to define a research agenda. }\end{array}$ & $\begin{array}{l}\text { Nine topics were defined as } \\
\text { priorities in the research agenda of } \\
\text { pre-hospital emergency services: } \\
\text { Non-transportation to the hospital } \\
\text { (highest ranked); Performance } \\
\text { measures for quality of care; Delivery } \\
\text { / registration / exchange of patient } \\
\text { data; Care and replacement of tasks; } \\
\text { Screening; Assessment of acute } \\
\text { neurological signs and symptoms; } \\
\text { Protocols and adherence to the } \\
\text { protocol; Immobilization; and Open / } \\
\text { protect by air. }\end{array}$ & 6 \\
\hline $\begin{array}{l}\text { Emergency Care } \\
\text { Handover (ECHO } \\
\text { study) across care } \\
\text { boundaries: the } \\
\text { need for joint } \\
\text { decision making } \\
\text { and consideration of } \\
\text { psychosocial history }\end{array}$ & $\begin{array}{l}2015 \\
\text { United } \\
\text { Kingdom }\end{array}$ & $\begin{array}{l}\text { Descriptive } \\
\text { exploratory } / n= \\
203 \text { case transfer } \\
\text { conversations }\end{array}$ & $\begin{array}{l}\text { The standardization of transfer needs } \\
\text { to accommodate collaborative } \\
\text { aspects and must incorporate the } \\
\text { communication of information relevant } \\
\text { to the patient's social and psychological } \\
\text { needs, in order to establish appropriate } \\
\text { care arrangements at the first } \\
\text { opportunity. }\end{array}$ & $\begin{array}{l}\text { The transfer of a case can involve } \\
\text { both descriptive conversations aimed } \\
\text { at transferring information and } \\
\text { collaborative conversations aimed at } \\
\text { joint decision-making. }\end{array}$ & 4 \\
\hline
\end{tabular}


Chart 1 (concluded)

\begin{tabular}{|c|c|c|c|c|c|}
\hline Article title & $\begin{array}{l}\text { Year } \\
\text { Country }\end{array}$ & $\begin{array}{l}\text { Outline/ number of } \\
\text { participants }\end{array}$ & Recommendations & Conclusion & $\begin{array}{l}\text { Level of } \\
\text { evidence }\end{array}$ \\
\hline $\begin{array}{l}\text { Managing competing } \\
\text { organizational } \\
\text { priorities in clinical } \\
\text { handover across } \\
\text { organizational } \\
\text { boundaries }^{(21)}\end{array}$ & $\begin{array}{c}2015 \\
\text { United } \\
\text { Kingdom }\end{array}$ & $\begin{array}{l}\text { Descriptive } \\
\text { exploratory / } \\
39 \text { professionals } \\
\text { working in pre- } \\
\text { hospital and in- } \\
\text { hospital emergency } \\
\text { medical services }\end{array}$ & $\begin{array}{l}\text { Organizations and regulators } \\
\text { may consider determining and } \\
\text { implementing quality indicators } \\
\text { to monitor the effectiveness of } \\
\text { interorganizational collaboration. These } \\
\text { quality indicators can include patient- } \\
\text { focused outcome measures that reflect } \\
\text { the entire path, as well as specific } \\
\text { process measures across borders. }\end{array}$ & $\begin{array}{l}\text { The transfer problems that } \\
\text { professionals experience in their daily } \\
\text { clinical practice are often associated } \\
\text { with organizational factors, such as } \\
\text { managing patient flows and time- } \\
\text { related performance goals. }\end{array}$ & 4 \\
\hline $\begin{array}{l}\text { Barriers to } \\
\text { implementation of a } \\
\text { redesign of } \\
\text { information transfer } \\
\text { and feedback in acute } \\
\text { care: results from a } \\
\text { multiple case study }\end{array}$ & $\begin{array}{c}2014 \\
\text { Netherlands }\end{array}$ & $\begin{array}{l}\text { Multiple case study / } \\
6 \text { cases }\end{array}$ & $\begin{array}{l}\text { Future efforts to redesign information } \\
\text { and feedback must begin with the } \\
\text { establishment of a sense of urgency, } \\
\text { and the "unlearning" of a routine should } \\
\text { receive the same effort as learning a } \\
\text { new one. }\end{array}$ & $\begin{array}{l}\text { In general, the results of the study } \\
\text { show a series of perceived barriers to } \\
\text { the implementation of a redesign of } \\
\text { information transfer and feedback in } \\
\text { acute care. Most barriers were related } \\
\text { to organizational routines and lack } \\
\text { of a sense of urgency to change the } \\
\text { practice. }\end{array}$ & 4 \\
\hline $\begin{array}{l}\text { Usage of documented } \\
\text { pre-hospital } \\
\text { observations } \\
\text { in secondary care: a } \\
\text { questionnaire study } \\
\text { and } \\
\text { retrospective } \\
\text { comparison of } \\
\text { records }\end{array}$ & $\begin{array}{l}2013 \\
\text { Norway }\end{array}$ & $\begin{array}{l}\text { Cross-sectional } \\
\text { questionnaire and } \\
\text { retrospective study / } \\
n=29 \text { professionals } \\
\text { of the in-hospital } \\
\text { emergency services } \\
\text { and } n=501 \text { records }\end{array}$ & $\begin{array}{l}\text { Several issues must be investigated: for } \\
\text { example, the clinical consequences of } \\
\text { omitting information and the flow of } \\
\text { verbal information and its use in clinical } \\
\text { decisions. }\end{array}$ & $\begin{array}{l}\text { Professional registrars in the } \\
\text { Emergency Department prefer } \\
\text { verbal case transfer and handwritten } \\
\text { prehospital reports based on clinical } \\
\text { information; and hardly ever use } \\
\text { digitized report forms. They also } \\
\text { perceive other doctors' clinical } \\
\text { information as more important than } \\
\text { information from ambulance teams. } \\
\text { Less than half of the potentially } \\
\text { important information documented } \\
\text { in the available pre-hospital notes is } \\
\text { transferred to hospital records. }\end{array}$ & 4 \\
\hline $\begin{array}{l}\text { Clinical handover in } \\
\text { the trauma setting: a } \\
\text { qualitative } \\
\text { study of paramedics } \\
\text { and trauma team } \\
\text { members }^{(24)}\end{array}$ & $\begin{array}{c}2010 \\
\text { Australia }\end{array}$ & $\begin{array}{l}\text { Descriptive } \\
\text { exploratory / } 27 \\
\text { professionals among } \\
\text { paramedics and } \\
\text { members of the } \\
\text { emergency team }\end{array}$ & $\begin{array}{l}\text { Provide frontline doctors with tools } \\
\text { and techniques to improve their ability } \\
\text { to collect information with minimal } \\
\text { burden and deliver it with seamless } \\
\text { integration between services in order to } \\
\text { improve results. }\end{array}$ & $\begin{array}{l}\text { Respondents stated that an effective } \\
\text { patient transfer was performed in a } \\
\text { succinct and structured manner and } \\
\text { contained only vital data necessary to } \\
\text { direct immediate treatment. }\end{array}$ & 4 \\
\hline
\end{tabular}

\section{Use of mnemonics in the patient's case transfer process}

Among the articles that present the use of mnemonics as a tool in patient transfer practices between pre-hospital and inhospital teams, the term SBAR (Situation-Background-AssessmentRecommendation) stands out as being the most cited among the authors ${ }^{(15-17)}$.

Also appear the terms MIST (injury/illness mechanism, sustained or suspected injury, signs, including observations and monitoring of the treatment given), ATMIST (age, time, injury / illness mechanism, sustained or suspected injury, signs, including observations and monitoring of treatment given), ABCDE (airway, breathing, circulation, disability and exposure) and AMPLE (allergy, medication, history, last meal, event) ${ }^{(15-17)}$.

The isolated use of mnemonic does not understand all the aspects necessary for an adequate case transfer. When the term MIST is used, it requires other complementary data such as temperature, categorization of the elements of the Glasgow scale, important medications and allergies ${ }^{(15)}$. Likewise, the term ATMIST, which is widely used in guidelines related to resuscitation in the United Kingdom, must be accompanied by psychosocial aspects ${ }^{(20)}$. In addition, it is necessary to standardize the processes, in which the terms AMPLE and ABCDE are inserted in the protocols, given the positive correlation of satisfaction between professionals when these terms were used and when the transfer process was structured ${ }^{(15)}$.
To this end, it is recommended to conduct research in the area of pre-hospital emergency services aimed at informing transfer and feedback designs as well as health impacts when there is an improvement in communication, given the scarcity of literature showing the use of structured tools (using mnemonics) in order to improve communication during patient transfer of case ${ }^{(24)}$.

Still, it must be considered that, for the implementation of new models of information transfer and feedback, some barriers must be broken: for example, the lack of a sense of urgency to improve, methods used in the process of implementing these models, as well as the existing routines in institutions, often described as highly stable, leading to institutional inertia(22).

\section{Barriers to case transfer}

Regarding the nurses' satisfaction in the case transfer process, there is a negative correlation between satisfaction and the sharing of information about the patient, as there is no structured process. There is a lack of information, as well as a discrepancy between the data passed to the hospital before the patient's arrival and his / her real state during the transfer of the case $\mathrm{e}^{(16)}$.

The lack of leadership identification was also a problem identified $^{(16-21)}$, in relation to which a study with 12 nurses showed the need to clearly identify to whom the case will be reported, since this is also a process of transferring responsibilities and essential 
for the continuity of care ${ }^{(16)}$. It is also pointed out that medical professionals of some specialties accept only patients who meet highly specific criteria, which can overburden the emergency department and lead to delays in care ${ }^{(21)}$.

Another important point to be highlighted is the lack of written information that could be consulted later ${ }^{(15,21-22)}$. It was observed that ambulance professionals used mostly memory during the transfer of information in the transfer of the case and, when they documented it in writing, they did it in inappropriate places, such as gloves, loose sheets and bedding ${ }^{(15)}$.

Even when the information was documented in a standardized form, no more than $30 \%$ of the parameters covered were passed on to the hospital admission form; and, when the information was forwarded by link, data such as patient immobilization measures and fluids administered intravenously were passed on less than a third of the time ${ }^{(23)}$. This occurs although the electronic transfer of data is seen as a way to improve the loss of information and avoid transcription errors ${ }^{(15)}$.

The importance of feedback on the transferred patient was also highlighted ${ }^{(16-22)}: 43.4 \%$ of survey respondents point to the need for improved feedback as very urgent, which is indicated as more common among specialists than among specialists and ambulance professionals ${ }^{(22)}$. This was also a topic presented as a research priority in countries like Canada, Australia and the United Kingdom ${ }^{(19)}$.

Another aspect to mention is the lack of physical and acoustic structure of the emergency departments, which disturbs the concentration of professionals involved at the time of passing the case, but it also removes the patient's privacy, as anyone who approaches can hear the verbal transfer of confidential information ${ }^{(17)}$.

Along with this, the time targets established by the unit managers are added to optimize care for victims: if, on the one hand, this pressure can create a corporate focus, on the other, it can favor the adoption of informal practices that can compromise patient safety ${ }^{(21)}$.

\section{DISCUSSION}

Based on the results presented, the use of mnemonics was obtained as a useful tool during case transfer; the most prominent term was SBAR, a validated and proven instrument for the transfer of information between health professionals. However, even this one needs modifications, giving rise to other terms such as ISBAR, in which the letter "I" refers to "identification", in order to remind the professional to identify the patient and him/ herself ${ }^{(25)}$. Similar changes occur with the term MIST, in which the letters " $\mathrm{A}$ " and "T" were added (forming ATMIST), relating to the patient's age and the time of the event ${ }^{(26)}$.

As for the term $A B C D E$ as a transfer tool, there is no consensus. In the Netherlands, the term is used to inform the transfer of case the same data as the advanced life support protocol ${ }^{(15)}$, whereas, in the UK, it was developed as a tool for shift change between teams, giving an overview of the sector ${ }^{(27)}$.

When carrying out a case transfer, it is also important to address the psychological and social aspects of patients ${ }^{(20-21)}$, since most of those who arrive at the emergency department are elderly, this being a concern in the Brazilian scenario, because the epidemiological profile of those assisted in emergencies has been increasing due to the demand of this age group. Added to this, the reasons that lead such a group to this service, which are usually aggravations of chronic conditions, added to multiple comorbidities and changes in mental state ${ }^{(28)}$. These facts present themselves as barriers to care, since less than 3\% of case transfers presented information about the psychosocial conditions of patients who arrived from the ambulance to the emergency department ${ }^{(20)}$

The absence of psychosocial information is directly related to the interference of the institutions in the work process, so that the imposed time targets affect the quality of the case transfer. When trying to adapt to these goals, in order to pass the case on and return to the operational base, the professional who works in the ambulance ends up having to optimize the time and shorten the amount of information to be transmitted; because of this, psychological and social aspects are typically the most

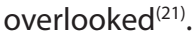

Such aspects can be considered in the history stage of some mnemonics, such as that of SBAR and AMPLE. When caring, the professional needs to have an integral look at the patient, including all of his biopsychosocial aspects, even in an emergency situation.

With regard to the lack of established leadership at the time of delivery of the patient, there is: the lack of consensus to where the patient who lacks multiple specialties should be sent; and the refusal of the medical team to assist patients who do not meet strict health standards ${ }^{(21)}$. Such impediments can cause queues in the emergency services and increase the workload of ambulance professionals, who can only leave the place when some professional of the in-hospital service take on the patient ${ }^{(29)}$.

Another important point that corroborates this problem is the multiple patient reception systems: in some places, the nurse is responsible for waiting for the pre-hospital service to arrive; in others, the doctor receives the team. However, there are places where no one is waiting: the ambulance professional has to enter the emergency service in search of leadership to transfer responsibility for the patient ${ }^{(16)}$.

As for the changes that can improve the processes and workflows predetermined by the institutions, the routines already established as a barrier can be cited, because there may be a stability of the transfer models and also an institutional inertia, the result of which is the plastering of the patient's conduct of receiving cases $^{(22)}$.

The feedback of the information passed on has also been shown to be an important way to improve the transfer process since it allows determining the success of the communication ${ }^{(1)}$; however, it is not adopted as mandatory conduct by institutions. In addition, the perception of urgency of professionals involved in acute care is a factor that limits the scope of changes in the existing model for transferring cases $^{(22)}$.

It is also important to have feedback from professionals in the hospital for pre-hospital professionals, because, when they are aware of the patient's outcome, there may be learning points ${ }^{(22)}$, but, for that, it is necessary a training enabling the professionals to follow models and techniques to receive such information.

As a form of intervention to try to make the communication process, in this scenario, have a positive impact on the transfer 
of a case, since time is restricted and the need for interventions is immediate, it is proposed that the data flow be structured, standardized $^{(16,19,30)}$ and integrated with the team ${ }^{(15-21,30)}$.

Concerning the discrepancy of information between the patient's real state and that informed before their arrival, it could be avoided with the adoption of electronic data transmission, which would possibly also improve transcription errors as well as communication failures when information is passed on multiple times or when the environment is subject to noise interference ${ }^{(15)}$.

Despite the importance of communication and all the impact on health services, this is a topic that is rarely addressed when it comes to communication in emergency medical services ${ }^{(19,24)}$. Regarding research on the subject, there is a knowledge gap, confirmed in the findings of another study according to which, in research with 62 specialists in the field of emergency medical services, transferring the patient's case is one of the priorities of future research ${ }^{(19,22-24)}$.

\section{Study limitation}

The study has the limitation that the consultation was made in databases in the area of Health and Nursing. The inclusion of other databases may expand the scope of analysis of the communication process of transferring cases from pre-hospital to in-hospital services. In addition, it should be noted that, during the review process, no studies were found in the national territory, which limits an analysis of the Brazilian reality.

\section{Contributions to the Health area}

This study discloses some protocols that can collaborate to transfer the case closer to the real need of the patient and, thus, ensure adequate health care. It also contributes to the identification of barriers to this communication process, so that one can intervene early to avoid errors and incidents. In this sense, there is a need for further studies in the area to encourage the exercise of health professionals.

\section{CONCLUSIONS}

Transferring a patient's case is a dynamic, complex and poorly studied process, especially when thinking about the Brazilian reality. Several problems faced by pre-hospital and in-hospital teams can be perceived, from the loss of important information to structural and organizational problems.

In general, studies show the need to standardize the case transfer process, as well as integrative training of professionals and regular assessment of the teams involved in emergency medical services. This study is expected to provide support for future research.

\section{REFERENCES}

1. Broca PV, Ferreira MA.A comunicação da equipe de enfermagem de uma enfermaria de clínica médica. Rev Bras Enferm. 2018;71(3):951-8. doi: 10.1590/0034-7167-2017-0208

2. Milesky JL, Baptiste D, Shelton BK. An observational study of patient handover communications among nurses on an oncology critical care unit. Contemp Nurse. 2018;54(1):77-87. doi: 10.1080/10376178.2017.1416306

3. Maxfield DG, Lyndon A, Kennedy HP, Keeffe DO, Zlatnik MG. Confronting safety gaps across labor and delivery teams. Am J Obstet Gynecol. 2013;209(5):402-8. doi: 10.1016/j.ajog.2013.07.013

4. Rosa ERS, Oliveira GA, Freitas RBC, Mota SDA, Vitorio AMF. Metas internacionais de segurança do paciente na percepção de estudantes de enfermagem. Rev Rede Cuid Saúde [Internet]. 2017[cited 2019 Jun 06];11(1):1-3. Available from: http://publicacoes.unigranrio.edu.br/index. $\mathrm{php} / \mathrm{rcs} / \mathrm{article/view/4587/2435.}$

5. Fealy G. Clinical handover practices among healthcare practitioners in acute care services: a qualitative study. J ClinNurs. 2018;28(1-2):80-8. doi: $10.1111 /$ jocn. 14643

6. Deniz N, Noyan A, Ertosun ÖG. The relationship between employee silence and organizational commitment in a private healthcare company. Procedia Soc Behav Sci. 2013;99(6):691-700. doi: 10.1016/j.sbspro.2013.10.540

7. Tibães HBB. Perfil de Atendimento do Serviço de Atendimento Móvel de Urgência no Norte de Minas Gerais. Rev Pesqui: Cuid Fundam. 2018;10(3):675-82. doi: 10.9789/2175-5361.2018.v10i3.675-682

8. Ministério da Saúde (BR). Portaria nº. 204805 de novembro de 2002. Aprova o regulamento técnico dos sistemas estaduais de urgência e emergência. Diário Oficial da União, Brasília, DF, 12 nov. 2002.

9. Soares MKP. Perfil dos usuários atendidos por um serviço pré-hospitalar móvel de urgência no nordeste brasileiro. Rev Pesqui: Cuid Fundam. 2018;0(2):503-9. doi: 10.9789/2175-5361.2018.v10i2.503-509

10. Pai DD Lima MADS, Abreu KP, Zucatti PB, Lautert L. Equipes e condições de trabalho nos serviços de atendimento pré-hospitalar móvel: revisão integrativa. Rev Eletron Enferm. 2015;17(4):1-12. doi: 10.5216/ree.v17i4.31522

11. Santos MC, Bernardes A, Gabriel CS, Évora YDM, Rocha FLR. O processo comunicativo no Serviço de Atendimento Móvel de Urgência (SAMU-192). Rev Gaúcha Enferm[Internet]. 2012;33(1):69-76. doi: 10.1590/S1983-14472012000100010

12. Mendes KDS, Silveira RCCP, Galvão CM. Revisão integrativa: método de pesquisa para a incorporação de evidências na saúde e na enfermagem. Texto Contexto Enferm. 2008;17(4):758-64. doi: 10.1590/S0104-07072008000400018

13. Principais itens para relatar Revisões sistemáticas e Meta-análises: a recomendação PRISMA. Epidemiol. Serv Saúde. 2015;24(2):335-42. doi: $10.5123 /$ S1679-49742015000200017 
14. Galvão CM, Sawada NO, Mendes IAC. A busca das melhores evidências. Rev Esc Enferm USP. 2003;37(4):43-50. doi: 10.1590/ S0080-62342003000400005

15. Hovenkamp GT. The satisfaction regarding handovers between ambulance and emergency department nurses: an observational study. Scand J Trauma ResuscEmerg Med. 2018;10;26(1):78. doi: 10.1186/s13049-018-0545-7

16. Sanjuan A. Handover of patients from prehospital emergency services to emergency departments: a qualitative analysis based on experiences of nurses. J Nurs Care Qual. 2018;34(2):169-74. doi: 10.1097/NCQ.0000000000000351

17. Kalyani MN, Fereidoun Z, Sarvestani RS, Shirazi ZH, Taghinezhad A. Perspectives of patient handover among paramedics and emergency department members; a qualitative study. Emerg (Tehran) [Internet]. 2017 [cited 2019 Jun 06];5(1):e76. Available from: https://www.ncbi. nlm.nih.gov/pmc/articles/PMC5703753/

18. Flynn D, Francis R, Robalino S, Lally J, Snooks H, Rodgers H, et al. A review of enhanced paramedic roles during and after hospital handover of stroke, myocardial infarction and trauma patients. BMC Emerg Med. 2017;17(1):5. doi: 10.1186/ s12873-017-0118-5

19. GlindI VD. A national research agenda for pre-hospital emergency medical services in the Netherlands: a Delphi-study. Scand J Trauma ResuscEmerg Med. 2016;24: 2. doi: 10.1186/s13049-015-0195-y

20. Sujan MA. Emergency Care Handover (ECHO study) across care boundaries: the need for joint decision making and consideration of psychosocial history. Emerg Med J. 2015;32(2):112-8. doi: 10.1136/emermed-2013-202977

21. Sujan MA. Managing competing organizational priorities in clinical handover across organizational boundaries. J Health Serv Res Policy. 2014;20(1-Suppl):17-25. doi: 10.1177/1355819614560449

22. Leijen-zeelenberg JEV. Barriers to implementation of a redesign of information transfer and feedback in acute care: results from a multiple case study. BMC Health Serv Res. 2014;3;14:149. doi: 10.1186/1472-6963-14-149

23. Knutsen GO, Fredriksen K. Usage of documented pre-hospital observations in secondary care: a questionnaire study and retrospective comparison of records. Scand J Trauma Resusc Emerg Med. 2013; 1;21:13. doi: 10.1186/1757-7241-21-13

24. Evans SM, Murray A, Patrick I, Fitzgerald M, Smith S, Cameron P. Clinical handover in the trauma setting: a qualitative study of paramedics and trauma team members. Qual Saf Health Care. 2010;19(6):e57. doi: 10.1136/qshc.2009.039073.

25. Alves M, Melo CL. Transferência de cuidado na perspectiva de profissionais de Enfermagem de um pronto-socorro. Rev Min Enferm. 2019;23:e-1194. doi: 10.5935/1415-2762.20190042

26. Slope R. Military and civilian handover communication in emergency care: how does it differ?. J Paramedic Pract. 2018;11(2):66-73. doi: 10.12968/jpar.2019.11.2.66

27. Farhan M. Brown R, Woloshynowych M, Vincent C. The ABC of handover: a qualitative study to develop a new tool for handover in the emergency department. Emerg Med J. 2012;29(12):941-6. doi: 10.1136/emermed-2011-200199

28. Soares ALA, Santos SP, Corpolato RC, Willig MH, Mantovani MF. Elderly care in the emergency department: an integrative review. Rev Bras Geriatr Gerontol. 2018;21(2):243-53. doi: 10.1590/1981-22562018021.170144

29. Hovenkamp GT, Olgers TJ, Wortel RR, Noltes ME, Dercksen B, TerMaatenJC.The satisfaction regarding handovers between ambulance and emergency department nurses: an observational study. Scand J Trauma Resusc Emerg Med. 2018;26(1):78. doi: 10.1186/s13049-018-0545-7.

30. Azevedo ALCS, Pereira AP, Lemos C, Coelho MF, Chaves LDP. Organização de serviços de emergência hospitalar: uma revisão integrativa de pesquisas. Rev Eletron Enferm. 2010;12(4):736-45. doi: 10.5216/ree.v12i4.6585 